\title{
How to sit on Two Sides of the Table? Swedish and Norwegian Unions' Approaches to Representative Worker Participation during the $20^{\text {th }}$ Century
}

\section{Katharina Sass'}

PhD Candidate, Department of Sociology, University of Bergen, Norway

\begin{abstract}
To this day, participation rights in Sweden have been reserved for union members both on the company level and on the board level, while all employees in companies, which are covered by respective agreements and laws, have voting rights in Norway. The aim of this article is twofold: First of all, it traces this difference back in time, using historical evidence from relevant periods of the $20^{\text {th }}$ century to illuminate how approaches of Swedish and Norwegian unions to representative worker participation evolved. Through the method of comparison, not only similarities and differences between the two countries but also continuities within the two union movements become apparent. It becomes clear that unions of both countries were worried about "double loyalties", but participation was more closely and deliberately linked with membership in Sweden. This in turn points to the second aim of the article, namely to identify possible reasons for this particular difference. Why were Swedish unions apparently more worried about "free riders"? While a final explanation will not be attempted here, one possible explaining factor is that private capital concentration was higher in Sweden and that Swedish employer organizations were more powerful. Swedish unions thus might have used membership requirements with regard to participation to avoid internal splits and to protect their comparatively high unity and density. This might have helped them to confront their, in comparison with Norway, better organized adversaries. The main aim of the article, however, is the first one, namely to give a synthetical, comparative account of Swedish and Norwegian unions' approaches to representative worker participation during the $20^{\text {th }}$ century, with a main focus on voting rights.
\end{abstract}

\section{KEY WORDS}

Board-level representation / Labor unions / Nonway / Sweden / Worker participation / Works councils

\section{Introduction}

abor unions played a crucial role throughout the $20^{\text {th }}$ century in all Scandinavian countries. They organized such large parts of the population that their impact on society, economy, and politics was immense, especially compared with other European countries (cf. Heiret et al., 2003; Korpi, 1978; Streeck \& Hassel, 2003). Even though union density has somewhat declined in recent decades, it is safe to assume that the study of labor unions still is key to understanding Nordic societies (Nergaard, 2010). However, recent developments in Nordic industrial relations should be analyzed with history in mind. How did labor unions in the Nordic countries manage to achieve what

\footnotetext{
${ }^{1}$ E-mail: katharina.sass@sos.uib.no
} 
they did? How did they deal with organizational challenges and contradictions? Which strategies and institutions did they develop in order to safeguard their internal unity and their political and market power? By studying questions like these, we become sensitive to the embodied history in existing labor unions, which again helps us to study the challenges they face at present.

Today, participation through works councils and board-level representatives is reserved for union members and federations in Sweden, while in Norway all employees in the covered companies have the right to elect representatives for these bodies (Justis-og beredskapsdepartementet, 1997a, 1997b, 2011; LO, 2013; Svensk Författningssamling, 2011, 2013). To trace this organizational difference between closely related labor movements back in time, to contextualize union strategies, and to highlight similarities and differences is the main aim of this article. A comparative-historical approach is chosen to illuminate how Swedish and Norwegian unions dealt with organizational challenges connected to worker participation from the period of their formation until approximately the 1970s. In addition, possible causal relations will be discussed, which might partly explain the discovered difference. The main emphasis is on the time periods after the First World War (WWI) and the Second World War (WWII) and the 1960s/1970s, because these were periods in which important debates and legal changes took place.

Since then, organizational challenges related to worker participation have not diminished, rather the contrary. Despite rising levels of education, promises of individual emancipation, good work, democratic rights, and a good life for all are undermined by capitalism's logic of profit, which, despite new management concepts and less authoritative business structures, is still in operation. The current international crisis illustrates this well, and it also shows why the question of worker participation has remained upto-date (cf. Meine et al., 2011).

But both old and new forms of worker participation present challenges for the unions (cf. Dörre, 2002; Demirović, 2007; Streeck, 1979). For even if one believes in principle in the merit of democratic mechanisms within capitalist enterprises, it is still not clear what these mechanisms should look like. Who should be involved in decisionmaking and at what level? What effects does it have for unions, when workers come to "sit on both sides of the table"? How to make sure that worker participation in single businesses does not lead to fiercer competition between groups of wage earners, but contributes to broad social solidarity? How to make sure that strong groups would not take advantage of their position without taking weaker groups into account, thereby threatening the organizations' unity? These questions are as old as the labor movement itself. It is therefore highly valuable to study unions' approaches to worker participation over time.

The article is structured as follows: First, some central theoretical perspectives on worker participation will be presented. Second, the comparative approach and methodological base of the article will be explained. Next, the historical evidence on unions' attitudes toward worker participation will be summarized for the three periods under consideration. Thereby, union strategies will be traced back in time and put into historical context, such as capital distribution and structure, the strength of employer organizations, and the politics of the labor parties in both countries. A table will serve to give an additional overview over important dates and events. Finally, some careful conclusions will be drawn, which may be of value for future discussions. 


\title{
Worker participation as an organizational challenge
}

As Demirović (2007, p. 30, translation by the author) points out, worker participation should not be reduced to any single institution:

\begin{abstract}
"Worker participation consists of a whole bundle of elements: of the democratic attitude among wage earners, their self-organization in unions, the collective agreements and industrial disputes, of union workplace representatives, works councils and general works councils, participation in board-level decision making, participation in public institutions such as the social and work administration or public media bodies, [and] of economic and statistical expertise and advise."1
\end{abstract}

Here, the focus is on the strategies developed by Swedish and Norwegian unions with regard to two specific forms of representative worker participation: work councils and board-level representation. Works councils can be defined as:

\begin{abstract}
"Permanent elected bodies of workforce representatives (or occasionally joint committees with employer representatives) set up on the basis of law or collective agreements with the overall task of promoting cooperation within the enterprise for the benefit of the enterprise itself and employees by creating and maintaining good and stable employment conditions, increasing welfare and security of employees and their understanding of enterprise operations, finance and competitiveness.” (Carley et al., 2005, p. 7)
\end{abstract}

The different "councils" and "committees" appearing in the course of history and mentioned in this article are all covered by this definition. Despite different names, it is argued that they were specifications of the same, albeit changing, kind of institution. Nonetheless, there are of course important differences between them, such as differences in practical importance and coverage (cf. endnotes 10 and 13). It should also be noted that it makes a strategic difference for unions whether such bodies are introduced through law or agreement. It has been observed that state intervention has been more common in Norway than in Sweden (cf. Kjellberg, 1999, p. 61). While this is worth an analysis of its own, the focus of this article shall rest on who has been allowed to vote or appoint the members, both in cases of works councils set up by agreement and by law. Employee board-level representation was first established in the German iron and steel industry in 1951 and has since taken many different forms (Gold, 2011, p. 41). It was introduced in Norway and Sweden during the 1960s (see Tab. 1).

When analyzing why works councils and board-level representation constitute organizational challenges for unions, it is helpful to consider Hyman's (2001) distinction between the three identities of trade unions. Firstly, all trade unions are to some extent actors in the class struggle, even if this struggle has been largely institutionalized. Socialdemocratic industrial unions in particular are supposed to represent the interests of the working class as a whole. This means that their goals cannot be identical with the goals of just one of their member groups, for example, the particular interests of the workforce of a single company. They have to integrate diverging interests against the interest of capital (Streeck, 1979). Secondly, trade unions are market actors. Of course, labor is a "fictitious commodity", which cannot be separated from the worker himself (Polanyi, 1957). More generally, a free labor market is an illusion, because markets are always 


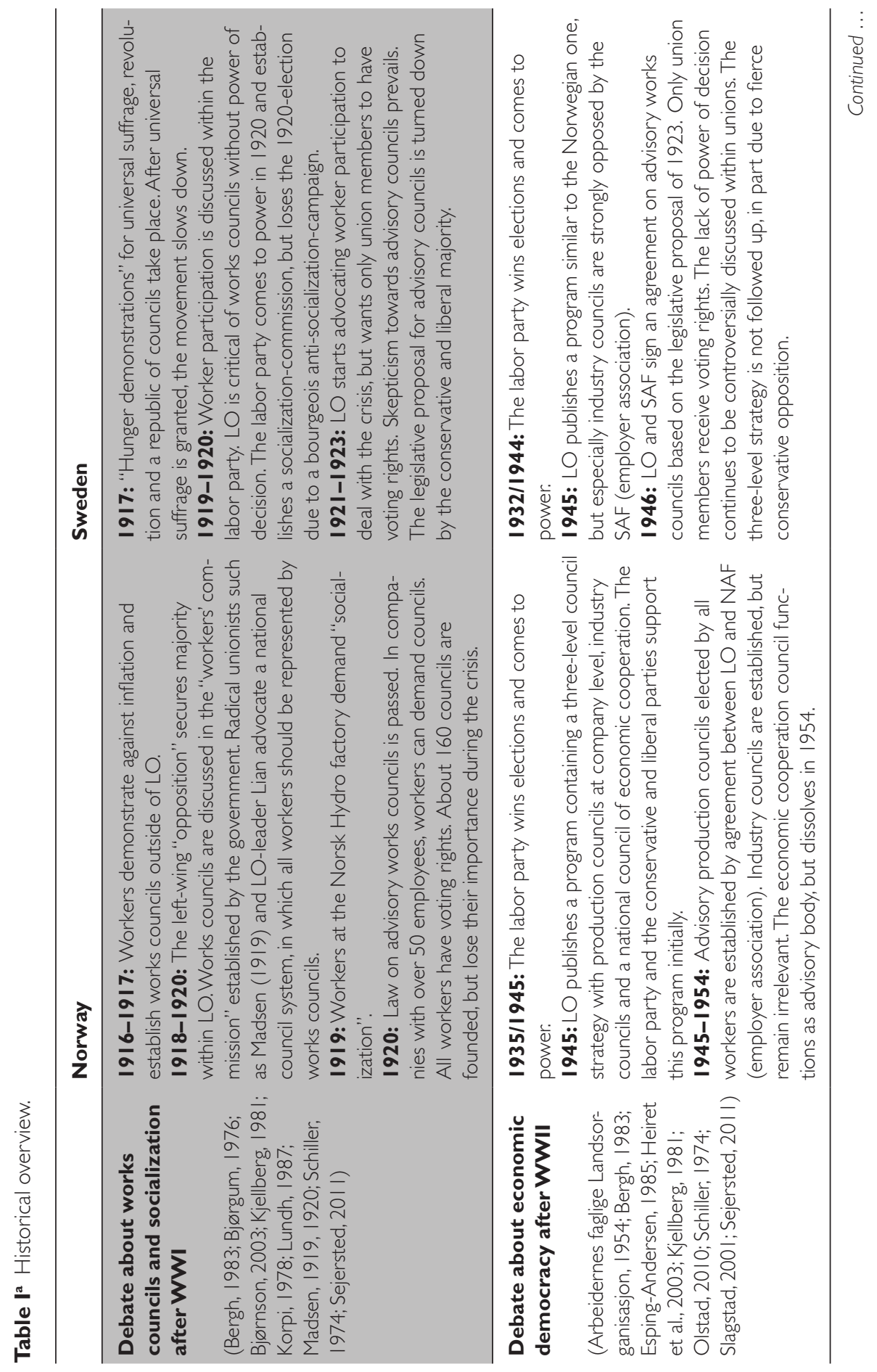




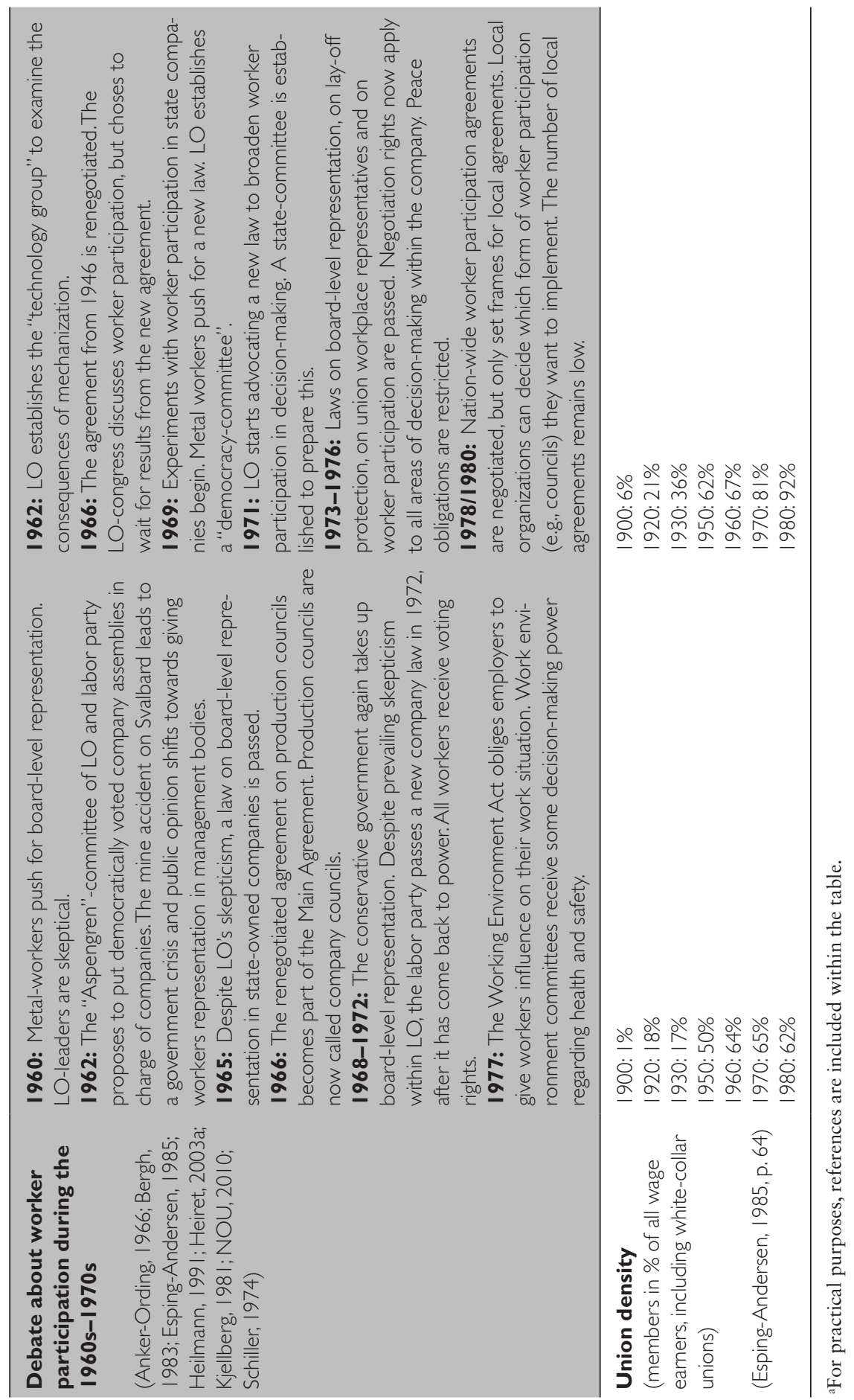


to some extent embedded in social institutions (Crouch \& Streeck, 1997; Hyman, 2001, p. 11). Despite, or maybe rather because of this, trade unions aim to monopolize labor in order to enhance its market power and value. From this perspective, broad cooperation between all wage earners, no matter where they work, is also clearly desirable. Finally, trade unions are a part of civil capitalist society and as such have tended to contribute to the stability thereof. They have become "social partners" in relation to capital and have helped to create a system of industrial relations that serves to temper social tensions. While fighting for, and of course in part achieving, the humanization of capitalism, they have contributed to the stability of capitalism itself. The problem of protecting the unions' unity in the class struggle is therefore related to the necessity to discipline internal anti-capitalist tendencies (cf. Streeck, 1979). In both cases, control mechanisms are necessary to counter internal opposition or particularistic tendencies. Far-reaching worker participation in single companies is then not so much regarded as a "step towards a socialist society", but more as a danger to the stability of the existing balance of power, which one has come to terms with (Anker-Ording, 1966).

Nevertheless, as actors in the class struggle, the industrial unions of Norway and Sweden have traditionally advocated worker participation, because many of their members have agreed with Marx that work should become an "end in itself" (Marx, 1972, p. 828; cf. Anker-Ording, 1966). Such work must no longer be alienated, but democratically organized, free work, with a positive and humane meaning (cf. AnkerOrding, 1966, p. 37). As market actors, the Nordic industrial unions also had pragmatic reasons to advocate forms of union workplace representation: to stay in touch with their members and to be able to mobilize them (Streeck, 1979, pp. 724ff). Despite this, unions have at times been skeptical of advisory works councils voted by all employees and of board-level representation (Heiret, 2003a; Kjellberg, 1981). The danger lies in having to "sit on both sides of the table", because this can lead to "deals" between local workforces and management, or because inexperienced or even nonunionized workers' representatives can be "cheated" by management into agreeing to policies that increase competition between all wage earners. ${ }^{2}$ Also, works councils can potentially be used against established union clubs and union workplace representatives by employers. This again can threaten class solidarity, internal unity, and thereby also the power position on the labor market. ${ }^{3}$ In this context, local wild strikes, possibly led by communist or syndicalist union currents, can also represent a danger from the point of view of social-democratic industrial unions aiming for consolidation of their power position within capitalist society. This means that industrial unions have to deal with a "structural dilemma": They have to find ways to "discipline" their local organizational units to follow the collective politics and strategy, while at the same time preserving the important functions of these local units (Streeck, 1979, p. 727). They have to make the most of any influence they can have on the company level, both from a class and from a market perspective, while at the same time preserving and protecting their internal unity. How industrial unions tackle this problem is strongly related to the system of industrial relations within which they maneuver (Streeck, 1979, p. 727).

For all these reasons, unions' approaches to works councils and board-level representation are not self-evident, but subject to contradictory organizational needs. That Swedish and Norwegian unions made different choices makes it relevant to study their organizational strategies comparatively. 


\section{A comparative design}

Methodologically, this study is based on both primary and secondary sources, including official publications of unions and social democratic parties, texts of union strategists from different periods, and a large number of historical-sociological case studies focusing on the development in either Norway or Sweden, sometimes including short asymmetrical comparisons. There are also a few explicitly comparative, and therefore highly useful, secondary sources (cf. Esping-Andersen, 1985; Kjellberg, 1999; Myrvang, 2001; Sejersted, 2011; Stenlås, 2001; Stråth, 2001).

Sweden and Norway make interesting cases, because the two countries have many similarities (cf. Sejersted, 2011, p. 9). They are normally classed into the same group in large-scale international comparisons, also when it comes to questions of worker participation (cf. Jackson, 2005). It is true that their trajectories are closely linked, not least due to extensive contact between community members. Nevertheless, important differences remain. Finding and analyzing these differences can help us understand the particularities of the social conditions of both countries. This is best done by what Ragin (1987) labels the "case-oriented method", in which complexity has precedence over generality, cases are examined as wholes, and causes are assessed in relation to context. One advantage of this kind of comparison is that it provides a rich account of the cases in question, which then shed light on each other (cf. Kocka, 2003; Skocpol \& Somers, 1980). To achieve this aim, historical integrity and context need to be highly valued. Many authors have argued that it is desirable even for comparisons of only few cases to also have an analytical function, meaning that they can serve to establish generalizable causal links (Hantrais, 2009; Kocka, 2003; Skocpol \& Somers, 1980). To what extent this is possible has been a subject of debate. Ragin (1987) and Welskopp (2010) are of the opinion that what Skocpol and Somers (1980) term "contrast of contexts" and "macro-causal analysis" do not necessarily have to contradict each other. The challenge lies in defining which factors present in one country, but not in the other, might have affected the historical outcome decisively. The present article will make some suggestions as to which factors might have been particularly relevant. But in view of the complexity and multicausality of the issues at hand, this should not be regarded as a final, but merely a possible partial explanation. On any account, comparing both cases should be conducive to a wider perspective. With regard to the discovered difference regarding membership requirements for participation, this particular comparison also led to the discovery of a new research question, which points to another advantage of comparative studies (cf. Hantrais, 2009; Kocka, 2003). In the following, the historical trajectories will be outlined, compared and analyzed for the three time periods in question.

\section{The debate on works councils and socialization after WWI}

As Tab. 1 shows, Norwegian unions embraced the idea of works councils early and connected it to radical visions of socialism. This was associated with ideas about broad cooperation within companies. For example, not only radical unionists such as Alfred Madsen $(1919,1920)$ but also less radical figures such as the LO-leader ${ }^{4}$ Ole O. Lian supported the idea of a national council system. Their idea of company councils was that they should have power of decision and that blue-collar and white-collar workers, as well as 
other representatives of society, should cooperate on an equal footing (Den skandinaviske arbeiderkongress, 1920, pp. 25, 41, cited in Bjørnson, 2003, pp. 72f). For them, this was a prerequisite for the modernization of production. Madsen (1919, p. 15) also thought that works councils would strengthen the unions and increase union density, because organized workers would quickly come to dominate them. This would give non-organized workers an incentive to organize. He thought that the existing union clubs were neither sufficiently legitimated nor powerful. Madsen (1919, p. 10) was aware of the danger of syndicalist tendencies, but assumed that solidarity between workers combined with democratic control would be strong enough to abolish destructive competition. While Lian supported negotiations with employers over worker participation, Madsen (1920, p. 11) argued against this, warning that the original idea could be transformed to serve the interests of capital. The employers, on the other hand, were opposed to works councils, mainly because they feared that national collective agreements could be replaced by local agreements, which would increase competition for labor (Bergh, 1983, p. 86; Bjørnson, 2003). This indicates that local union strength might have varied considerably. When advisory councils, elected by all employees, were established by law in 1920, the Norwegian unions considered this to be a small improvement, even though their practical importance was limited (Bjørnson, 2003, pp. 70ff).

In Sweden, the labor party put the idea of works councils on the agenda in 1919. Kjellberg (1981, p. 55) points out that the labor party was under pressure from the left to position itself more clearly on the question of economic democracy, now that political democracy had been achieved. ${ }^{5}$ The unions, on the other hand, remained skeptical of works councils. They did not believe that Swedish employers would agree to works councils with decision-making power, thereby giving up their own management rights, and they were worried that advisory works councils could be used against their existing union clubs, which had acquired some relevant influence in some industries. The possibility that employers would use works councils to drive wedges between groups of workers seemed a real danger. Therefore, the unions had no interest in a "works council experiment" (SAP, 1920, cited in Kjellberg, 1981, pp. 54ff; Socialdemokraterna \& Arbetarrörelsens arkiv och bibliotek, 2001, p. 37). When the economic crisis finally contributed to a gradual change of position, because unions had to prove to their members that they were not accepting lay-offs without a fight, they demanded that only union members should have voting rights for works councils. This was seen as necessary in order to prevent competition between union clubs and works councils. The legislative proposal of 1923 was supported by the LO president, but unpopular among most LO unions, in particular the Metalworkers' union (Kjellberg, 1981, pp. 57ff). But by that time, the political climate had shifted and employers and conservative and liberal parties were no longer interested in compromise, so the proposal was turned down (Lundh, 1987, pp. 494).

To attempt to understand this different development, one has to consider the different capital distribution and structure of both countries and the resulting difference of power balances. Industrialization began earlier in Sweden and capital concentration was higher. Heavy industry was developed from 1870 onward, while the Norwegian industrial sector was dominated by light industry for many decades to come. Technologybased Swedish businesses were internationally successful at an early date and Swedish capitalists could follow in the footsteps of traditional aristocratic authority. In Norway, traditional authority was swept aside more thoroughly when independence 
from Sweden was achieved in 1905, but this also meant that the country lacked institutional foundations for industrial development (Sejersted, 2011, pp. 15ff). As a consequence, private big business never gained an equally strong foothold as in Sweden (Esping-Andersen, 1985, p. 55). Probably in part as a result of this difference, the organizational density of unions has been higher in Sweden all through the 20th century (see Tab. 1). ${ }^{6}$ One could say that class opposition was tougher in Sweden (Esping-Andersen, 1985). However, class consciousness seemed to be more pronounced in Norway. The Norwegian labor movement was dominated by the left-wing current longer than the Swedish labor movement, which suffered a major defeat after the General Strike of 1909 , leading to massive membership losses, and which had to deal with more powerful employer associations (Bjørgum, 1976; Bjørnson, 2003; Kjellberg, 2000; Korpi, 1978, p. 62; Schiller, 1967). In the aftermath of this strike, the reformist current gained a majority both within the Swedish LO and the labor party. While the Norwegian labor party welcomed the Russian revolution and even joined the Comintern for some time, the Swedish labor party distanced itself and entered its first coalition-government with the liberal party in 1917 (Sejersted, 2011, pp. 141ff).

The different role of the liberal parties in both countries is also relevant. Norwegian politics were dominated by the liberal party ("Venstre") from 1884 until about 1940. It represented many different social groups, for example, lower white-collar employees, small business men, master craftsmen, and farmers. In the beginning, it also had social-democratic currents and was mainly held together by the desire of independence. Later, it became more interested in the regulation of class conflict and a democratic peaceful development, which also motivated its support for advisory works councils (Bergh, 1983, p. 86; Bjørnson, 2003, pp. 48ff; Bull, 1969, pp. 71f; Sejersted, 2011, p. 52). Employers could not always rely on this kind of party. In Sweden, the liberal party was not equally powerful and aristocratic-conservative influence on politics remained strong much longer (Sejersted, 2011, pp. 61ff). For all these reasons, the Swedish unions seem to have been in a more defensive position and possibly could not risk experimenting with advisory works councils the same way the Norwegian unions deemed it possible.

\section{The debate on economic democracy after WWII}

After WWII, both Norwegian and Swedish unions pushed for economic democracy and for the integration of works councils on the company level into a larger, three-level council system (see Tab. 1). Richard Sterner, the leading researcher of the Swedish LO, warned in a memorandum in 1943 that worker participation only on the company level could lead to particularistic alliances or to "hostage situations" for worker representatives (Ekdahl, 2001, p. 203, cited in Sejersted, 2011, p. 303). This had to be avoided. The unions' post-war programs were inspired by the general hope of creating a socialist system, but soon lost their relevance. This was related to the contradictory political situation: On the one hand, everyone saw the need to cooperate in order to modernize production and create growth. Even the Norwegian conservative and liberal parties signed the "common program" ("Fellesprogrammet"), which contained suggestions for a three-level council system. On the other hand, ideological resistance from the right against the implementation of such a program prevailed. This threatened the reform and growth strategies of the labor parties, which had come to power and faced the 
challenge of building up the economy. Within the labor movement, the unions of both countries had been relegated to second place. Consolidating social-democratic political leadership now became "an overriding goal" (Korpi, 1978, pp. 230f). Therefore, ideas about alternative economic power structures were set aside and compromise was sought where conservative resistance could not be overcome (cf. Bjørnhaug et al., 2000, p. 56; Sejersted, 2011, p. 305; 1993, pp. 188f).

In practice, this meant that works councils on the company level were established as advisory bodies only. In Norway, industry councils were also established by law, but so little supported by employers that they did not play a relevant role. The economic cooperation council on the national level became mainly an advisory body for the government and had no connection to the councils on the other levels (Bergh, 1983, p. 91; Heiret, 2003a, p. 113). In Sweden, no such bodies were even set up, because the employer organization SAF was fiercely opposed to them (Sejersted, 2011, pp. 304f). According to Kjellberg (1981, pp. 65f), the government's threat of intervention forced employers to accept at least some of the union's conditions, among them the important concession that only union members should have voting rights for the advisory works councils set up by agreement. This condition was defensive in nature: It was meant to prevent competition between works councils and union clubs. In Norway, all workers received voting rights for advisory works councils. Non-members and white-collar workers were not excluded (Arbeidernes faglige Landsorganisasjon, 1954). As in the period after WWI, the Norwegian unions did not consider this a problem for their internal unity. But they did see a problem in worker participation on the board-level, when this was discussed within the labor party during the $1950 \mathrm{~s}^{7}$ Here, they did not want to come to "sit on both sides of the table". They were worried that union representatives could make fools of themselves due to a lack of knowledge, or that they could be used as "hostages" of management. The cooperation committee of unions and labor party instead suggested that workers should not have representatives on the board, but the board should be elected by company assemblies, in which workers should have voting rights (Heiret, 2003a, pp. 138f; Sejersted, 1993, p. 188). Due to employer opposition and uncertainty within LO, nothing came out of this first attempt of the labor party regarding boardlevel representation (Bergh, 1983). But the discussion shows that Swedish worries were partly shared in Norway, just not to the same extent.

This might be related to the fact that opposition by Swedish employers was fiercer. Swedish employers had several advantages compared with Norwegian employers: They were better organized, they had had time to prepare strategies during the war, and they had more money for propaganda (Stenlås, 2001). ${ }^{8}$ For all these reasons, they neither wanted nor needed the state to regulate industrial relations (Kjellberg, 2000; Korpi, 1978, pp. 210ff). Norwegian employer associations, on the contrary, repeatedly asked for state intervention (Bjørnson, 2003; Dølvik \& Stokke, 1998, pp. 129f). This clearly supports Sejersted's hypothesis, that "the Norwegian Sonderweg [...] is characterized by the weakness of big business and the corresponding strength of the democratic petite bourgeoisie" (Sejersted, 2011, p. 11). And, it might also explain at least partly why Swedish unions were more worried about internal splits. It seems that history repeatedly "taught" the Swedish unions that internal unity was crucial if they wanted to retain their position as an influential factor in Swedish politics.

The union strategies may also be interpreted with respect to the unions' role as "social partners" in society (cf. Hyman, 2001). Clearly, unions in both countries were 
aware of their stabilizing function for the labor governments. They needed to make sure that no worker groups would make "irresponsible" wage demands, which could threaten government policies. Besides their worry that works councils would be used by employers to weaken union influence and create particularistic alliances, Swedish unions therefore also tried to minimize internal syndicalist tendencies and to prevent local strikes and instability of the system as a whole. Revolution was never really an issue, even though some radical propositions were fronted now and again to please eager members. Sweden's high capital concentration, powerful employers, and well-developing economy probably all made Swedish unions reluctant to tamper with the power balance they had achieved. They faced a stronger opponent than the Norwegian unions. And, the legitimacy of the existing system was so strong that seriously challenging it seemed unrealistic. Even though the same holds for Norway to a large extent, the Norwegian public was more critical toward employer strategies such as lockouts, and the government was more ready to interfere, not always to the employers' benefit (Bjørnson, 2003, p. 67; Sejersted, 2011, p. 153; Stenlås, 2001). The legitimacy of non-democratic, capital-based power was slightly weaker (Sejersted, 2011; Stråth, 2001). Also, Norwegian unions were possibly more concerned about modernization of production, because a modernizing strong capitalist class was missing (Sejersted, 1993, 2011). This could explain why Norwegian unions and labor government were slightly more open for new experiments deemed too risky by their Swedish counterparts.

\section{The developments in the 1960s and 1970s}

During the 1960s and 1970s, it became evident that unions needed to rethink their strategies. Awareness of health and environmental risks was rising and growing international competition, restructuring, and closure of companies constituted new challenges. Toward the end of the 1960s, the student protests contributed to a change of the political climate. Unions and labor parties were accused of acting too defensively and wild strikes were becoming more frequent (von Beyme, 1977, p. 125). Against this background, worker participation again became a major political topic.

In Norway, a radical proposition was fronted by the "Aspengren-committee", formed by unions and labor party, in 1962: It again suggested establishing company assemblies as new company organs, which were to have power of decision and in which unionists could act not as representatives of the company but as representatives of the workers. All workers should have voting rights (Anker-Ording, 1966). However, the mining accident in Svalbard led to a situation in which even the conservative and liberal parties advocated board-level representation in state-owned companies. Skepticism of employer organizations notwithstanding, especially the conservative party was now of the opinion that employees would be at least as capable as the state to make management decisions (Bergh, 1983, pp. 103ff). Despite the fact that Norwegian unions were still critical of direct representation on the board, the labor party therefore passed a law in 1965, which gave employees in state-owned companies the right to suggest representatives. The final appointment remained however in the hands of the state and LO's claim for company assemblies was unsuccessful (Bergh, 1983, pp. 104ff).

Both Swedish and Norwegian union federations renegotiated the agreements on works councils in 1966. Management was now supposed to confer with and inform 
worker representatives on more issues than before. In exchange, they should contribute their knowledge to increase profitability and pacify relations within the company (Heilmann, 1991, p. 205; Heiret, 2003a, p. 148; Schiller, 1990, p. 301f). Since then, company councils ("bedriftssutvalg") have been part of the Main Agreement between the Norwegian LO and the NAF. ${ }^{9}$ The relevant $\$ 12-3$ in today's Main Agreement still reads "All employees have the right to vote, except members of management" (LO, 2014). ${ }^{10}$ In practice, however, worker representatives on company councils are almost always organized (Falkum, 2013, personal communication). It seems that it is not difficult and has never been difficult, for the local branches of Norwegian unions to make use of the existing participation channels. ${ }^{11}$

While giving voting rights to non-members was not considered a danger to internal unity, board-level representation still was. LO therefore kept advocating the company assembly model to avoid "double loyalties" and to make sure that workers' representatives could continue to see the representation of workers as their main task (Bergh, 1983, p. 114, p. 120; Heiret, 2003a, pp. 147ff). However, employers as well as conservative and liberal parties now accepted board-level representation. Experiences in state-owned companies and in production councils had shown that cooperation could serve the interest of employers also (Heiret, 2003a, p. 149). Again following the "political logic", and despite LO's skepticism, the labor party revised the company law ${ }^{12}$ in 1972, giving all employees, including non-members and white-collar workers, the right to elect worker representatives for the board in the private sectors of industry and mining. Company assemblies were introduced for companies with more than 200 employees (Justis-og beredskapsdepartementet, 1976; Stortingstidende, 1971-1972). Similar laws were later passed to cover the state-owned companies and other sectors (Bergh, 1983, pp. 117ff). Also, the Working Environment Act from $1977^{13}$, with its rather far-reaching regulations on self-determination, workers' influence on the work and protection from physical and psychic burdens, is built on the principle that all employees, regardless of union membership, have voting rights. The law is still in place today. Regarding board-level representation, the last radical proposal in Norway was made by the Skytøen-committee of unions and labor party in 1980, which suggested increasing representation of employees on the board and in company assemblies to $50 \%$ (LO, 1980). While this proposal might indicate that LO's worries regarding board-level representation were now in the past, it was not followed up by the government (cf. Heiret, 2003b, pp. 186ff, for a more detailed discussion).

In Sweden, the SAF had to consider the interests of the family businesses in its ranks, which were massively opposed to workers' representation on the board. Contrary to the NAF, the SAF was not willing to compromise on the subject (Schiller, 1990, pp. 350f). Schiller (1990, pp. 305f) points out that the board-level participation debate was seen as a minor question by the unions compared with more far-reaching proposals, such as the idea of wage earner funds ${ }^{14}$, and mainly served the strategic purpose of showing the public that employers had to be forced by law to give workers any influence. According to Heilmann (1991, pp. 206f), the focus on direct worker participation "from below", which Swedish unions now emphasized in their struggle for the Co-Determination in the Workplace Act ("Medbestämmendelagen"), diminished traditional worries about "double loyalties" with regard to board-level participation. Nevertheless, the tradition of giving voting rights to union members only prevailed. The law on workers' representation in management from 1973 gave unions the right to delegate two workers' 
representatives and two substitutes to the board of directors (Svensk Författningssamling, 2014c). The modern Swedish Board Representation (Private Sector Employees) Act, which replaced the 1973 law, contains detailed provisions for how worker seats in management are to be distributed between the different union federations present at a workplace (Svensk Författningssamling, 2014a). Also in the Co-Determination in the Workplace Act, which has been in place since 1976, all rights apply to organizations, not to individual employees, which means that non-members do not receive any influence (Svensk Författningssamling, 2014b). This law opens-in theory-for far-reaching local agreements on worker participation, but in practice, it led to few local agreements (cf. Kjellberg, 1981, p. 76; Heilmann, 1991).

A detailed discussion of the Swedish struggle around the wage earner funds (cf. Endnote 14) falls out of the scope of this paper, but one last observation by Sejersted (2011, pp. 376f) is interesting: Again, Sejersted (2011, pp. 376f) points out that there was much less concentration of private capital in Norway than in Sweden ${ }^{15}$, which might explain why this idea originated in Sweden and never gained ground in Norway. The difference might also have contributed to the Norwegian unions' argument that workers should have influence in their capacity as workers, not as owners (Sejersted, 2011, p. 376). As we have seen, this line of thought was meant to apply for all workers, regardless of union membership.

\section{Conclusion and outlook}

Clearly, today's laws and agreements result at least partly from organizational strategies and traditions, which evolved during critical periods of union history. As the comparison has shown, Swedish unions across time put more emphasis on the idea that only union members should be involved in representative worker participation. They remained skeptical of works councils longer and saw union membership as a safety requirement to prevent internal splits, also when it came to board-level representation. Nevertheless, Norwegian unions were also aware of the dangers of "double loyalties". But they were less worried about "free riders" and rather sure of their own capacity to monopolize participation channels.

Considering the lower union density in Norway, this conclusion might seem surprising (cf. Tab. 1; Endnote 6). Without a doubt, Swedish unions were well-organized and strong. Why Norwegian unions still felt less need for the membership-related precautions Swedish unions took, therefore constitutes a paradox, which needs to be analyzed further. However, it is likely that the different strength of the employer organizations and the different class structures at least were important factors (cf. Endnote 14). It is a possibility that the employers' capacity of driving wedges between groups of workers was greater in Sweden, and that the unions reacted to this, for example, with a more restrictive policy regarding the membership requirement for participation. In terms of union density, their strategy seems to have paid off, even though union density is of course influenced by many factors (cf. Endnote 6).

How the historical trends affect today's situation cannot be examined in detail here, but a few points may be mentioned: The fact that Swedish employers exited centralized bargaining and corporative bodies in 1990/1991, while the Norwegian employers still take part might indicate that Swedish employers still have more power (cf. Sejersted, 
2011, pp. 361ff, 378f). For Norway, Løken and Stokke's (2009, p. 49) evaluation is that board-level representation is "generally accepted and viewed positively" - they do not mention the contradictions inherent in this institution. This might be related to Gold's (2011) observation that the comparatively close links Nordic worker representatives still have with their unions help them to experience their position as less contradictory. They are safely anchored in the union network and cannot succumb to company particularism in the way less well-organized worker representatives possibly could (cf. Hagen, 2010, for figures on Norway). Nevertheless, this does not resolve the underlying tension between the interests of workers and management. In times of economic recession, that tension might come to the fore once more.

For the unions, this means that dealing with particularistic tendencies in a way that protects internal unity and solidarity is still an important issue. In particular, the decentralization of wage negotiations, which is to some extent taking place in Sweden, presents a challenge for class solidarity (cf. Kjellberg, 2009). On the other hand, decentralized and direct worker participation might open up new opportunities for far-reaching changes. In Norway, approaches to worker participation vary locally and between sectors (Falkum et al., 2009). How Norwegian unions, as well as employers, make use of the existing participation structures, and how unions have come to dominate them despite the fact that this is not legally regulated would be well worth further study (Falkum, 2013, personal communication). Clearly, the study of unions' strategies regarding worker participation is far from finished.

\section{Acknowledgements}

I thank Ann Nilsen, Ole Johnny Olsen, Rune Sakslind, Wolfgang Streeck, Ørjar Øyen, Eivind Falkum, and Gisle Andersen for their constructive and generous advice.

\section{References}

Anker-Ording, A. (1966) Betriebsdemokratie in Norwegen. Weg zur sozialistischen Gesellschaft. [Worker participation in Norway. Path to a socialist society.] Frankfurt am Main: Europäische Verlagsanstalt.

Arbeidernes faglige Landsorganisasjon (1954) Overenskomst om produksjonsutvalg mellom Arbeidernes faglige Landsorganisasjon og Norsk Arbeidsgiverforening, 1950. [Agreement on production councils between The Norwegian Federation of Trade Unions and the Norwegian Employer Association, 1950.] Oslo: Arbeidernes Aktietrykkeri.

Bergh, T. (ed) (1983) Deltakerdemokratiet. Teori og praksis. [The participatory democracy. Theory and practice.] Oslo: Universitetsforlaget.

Bjørgum, J. (1976) 'Fagopposisjonen av 1911' [The union opposition of 1911], Tidsskrift for arbeiderbevegelsens historie 1976(1): 63-131.

Bjørnhaug, I., Bjørnson, Ø., Halvorsen, T. and Ågotnes, HJ. (2000) 'Solidaritetens grenser. Tariffpolitiske betraktninger i et hundreårsperspektiv.' [The borders of solidarity. Considerations on collective bargaining in a centennial perspective.] In: Bjørnhaug, I., Bjørnson, Ø., Halvorsen, T. and Ågotnes, HJ. (eds) I rettferdighetens navn. LO 100 àr - historiske blikk på fagbevegelsens meningsbrytninger og veivalg. Oslo: Akribe, pp. 17-126. 
Bjørnson, Ø. (2003) 'Kamp og krise: Framveksten av et organisert arbeidsliv i privat og statlig sektor 1900-1940.' [Struggle and crisis: The development of an organized working life in the private and state sector 1900-1940.] In: Heiret, J., Korsnes, O., Venneslan, K. and Bjørnson, Ø. (eds) Arbeidsliv, historie, samfunn. Norske arbeidslivsrelasjoner $i$ historisk, sosiologisk og arbeidsrettslig perspektiv. Bergen: Fagbokforlaget, pp. 45-108.

Bull, E. (1960) Die norwegische Gewerkschaftsbewegung. [The Norwegian trade union movement.] Köln: Bund-Verlag.

Bull, E. (1969) Sozialgeschichte der norwegischen Demokratie. [Social history of the Norwegian democracy.] Stuttgart: Ernst Klett Verlag.

Carley, M., Baradel, A. and Welz, C. (2005) 'Works councils: Workplace Representation and Participation Structures.' Dublin: European Foundation. Available online at: http://www. eurofound.europa.eu/pubdocs/2004/143/en/1/ef04143en.pdf (accessed 5 January 2014).

Crouch, C. and Streeck, W. (eds) (1997) Political Economy of Modern Capitalism. London: Sage.

Demirović, A. (2007) Demokratie in der Wirtschaft. Positionen. Probleme. Perspektiven. [Democracy in the economy. Positions. Problems. Perspectives.] Münster: Westfälisches Dampfboot.

Den skandinaviske arbeiderkongress (1920) Referat fra forhandlingene. [The Scandinavian workers' congress. Protocol of the discussions.]

Dølvik, JE. and Stokke, TA. (1998) 'Norway: The Revival of Centralized Concertation.' In: Ferner, A. and Hyman, R. (eds) Changing Industrial Relations in Europe. Oxford: Blackwell, pp. 118-145.

Dörre, K. (2002) Kampf um Beteiligung. Arbeit, Partizipation und industrielle Beziehungen im flexiblen Kapitalismus. [Struggle for participation. Work, participation and industrial relations in flexible capitalism.] Wiesbaden: Westdeutscher Verlag.

Ekdahl, L. (2001) Tysk flyktning och svensk modell. Vol. 1 in Mot en tredje väg. En biografi över Rudolf Meidner. [German refugee and Swedish model. Vol. 1 in Towards a third way. Biography of Rudolf Meidner.] Lund: Arkiv förlag.

Esping-Andersen, G. (1985) Politics Against Markets. The Social Democratic Road to Power. Princeton: Princeton University Press.

Falkum, E. (2008) 'Makt og opposisjon i norsk arbeidsliv. Avhandling for dr.philos.-grad' [Power and opposition in Norwegian working life. Thesis for dr.philos. degree]. Oslo: Fafo-rapport 2008: 31.

Falkum, E., Hagen, IM. and Trygstad, SC. (2009) 'Bedriftsdemokratiets tilstand. Medbestemmelse, medvirkning og innflytelse i 2009.' [The current state of industrial democracy. Codetermination, participation and influence in 2009.] Oslo: Fafo-rapport 2009: 35.

Gold, M. (2011) “Taken on board': An evaluation of the influence of employee board-level representatives on company decision-making across Europe'. European Journal of Industrial Relations 17(1): 41-56.

Grünfeld, LA. and Jakobsen, EW. (2006) 'Hvem eier Norge? Eierskap og verdiskaping i et grenseløst næringsliv.' [Who owns Norway? Ownership and value creation in a borderless economy.] Oslo: Universitetsforlaget.

Hagen, IM. (2010) 'Det mektige mindretallet. Ansatterepresentasjon i styret mellom Corporate Governance og Industrial Relations. Doktoravhandling.' [The powerful minority. Employee representation on the board between Corporate Governance and Industrial Relations. PhD-thesis.] Oslo: Fafo-rapport 2010: 02.

Hagen, IM. and Trygstad, SC. (2009) 'Local flexicurity: resolving the conflict between direct and representative participation.' Transfer: European Review of Labour and Research 15(3-4): 557-577.

Hantrais, L. (2009) International Comparative Research. Theory, Methods and Practice. Basingstoke: Palgrave Macmillan. 
Heilmann, J. (1991) 'Der schwedische Weg zur Demokratie am Arbeitsplatz. Zur jüngeren Geschichte des Mitbestimmungsgesetz von 1976.' [The Swedish path to democracy at the work place. On the recent history of the law on employee participation of 1976.] Archiv für Sozialgeschichte 31: 197-216.

Heiret, J. (2000) Konsernfaglig samarbeid mellom demokratisering og ledelse. [Corporate cooperation between democratization and management.] In: Bjørnhaug, I., Bjørnson, Ø., Halvorsen, T. and Ågotnes, HJ. (eds) I rettferdighetens navn. LO 100 ar - historiske blikk på fagbevegelsens meningsbrytninger og veivalg. Oslo: Akribe, pp. 279-305.

Heiret, J., Korsnes, O., Venneslan, K. and Bjørnson, Ø. (eds) (2003) Arbeidsliv, historie, samfunn. Norske arbeidslivsrelasjoner i historisk, sosiologisk og arbeidsrettslig perspektiv. [Working life, history, society. Norwegian industrial relations in historical, sociological and labour law perspective.] Bergen: Fagbokforlaget.

Heiret, J. (2003a) Samarbeid og statlig styring 1945-1977. [Cooperation and state management 1945-1977.] In: Heiret, J., Korsnes, O., Venneslan, K. and Bjørnson, Ø. (eds) (2003) Arbeidsliv, historie, samfunn. Norske arbeidslivsrelasjoner i historisk, sosiologisk og arbeidsrettslig perspektiv. Bergen: Fagbokforlaget, pp. 109-176.

Heiret, J. (2003b) Et nasjonalt system i en internasjonal verden 1978-2003. [A national system in an international world 1978-2003] In: Heiret, J., Korsnes, O., Venneslan, K. and Bjørnson, Ø. (eds) (2003) Arbeidsliv, historie, samfunn. Norske arbeidslivsrelasjoner i historisk, sosiologisk og arbeidsrettslig perspektiv. Bergen: Fagbokforlaget, pp. 177-245.

Hyman, R. (2001) Understanding European Trade Unionism. Between Market, Class \& Society. London: Sage.

Jackson, G. (2005) 'Employee Representation in the Board Compared: A Fuzzy Sets Analysis of Corporate Governance, Unionism and Political Institutions.' Industrielle Beziehungen 12(3): 1-28.

Justis- og beredskapsdepartementet (1976) Forskrift om de ansattes rett til representasjon i aksjeselskapers styre og bedriftsforsamling m.v. [Regulation on employees' right of representation on the board and in the company assembly] http://lovdata.no/pro/\#document/ ROF/forskrift/1976-12-10-2/KAPITTEL_3.

Justis- og beredskapsdepartementet (1997a) LOV 1997-06-13 nr 44: Lov om aksjeselskaper (aksjeloven) [Norwegian Limited Liability Companies Act]. Available at: http://www.lovdata.no/all/nl-19970613-044.html (accessed 5 January 2014).

Justis- og beredskapsdepartementet (1997b) LOV 1997-06-13 nr 45: Lov om allmennaksjeselskaper (allmennaksjeloven) [Norwegian Public Limited Liability Companies Act]. Available at: http://www.lovdata.no/all/hl-19970613-045.html (accessed 5 January 2014).

Justis- og beredskapsdepartementet (2011) FOR 2011-12-06 nr 1355: Forskrift om organisering, ledelse og medvirkning. [Norwegian regulation on organisation, management and participation.] Available at: http://www.lovdata.no/for/sf/ad/xd-20111206-1355.html (accessed 5 January 2014).

Kjellberg, A. (1981) 'Från industriell demokrati till medbestämmande.' [From industrial democracy to co-determination.] Arkiv för studier i arbetarrörelsens historia 21-22: 53-82.

Kjellberg, A. (1988) 'Svensk fackföreningsrörelse ur internationellt perspektiv.' [Swedish trade union movement in an international perspective.] In: Olsson, L. and Hult, C. (eds) Arbetets historia 2. Arbetshistoriska seminariet, Historiska institutionen, Lunds universitet, pp. 85-96.

Kjellberg, A. (1999) 'Fagorganisering i Norge og Sverige i et internasjonalt perspektiv.' [Trade union organization in Norway and Sweden in an international perspective.] In: Arbeiderhistorie. Årbok for Arbeiderbevelsens Arkiv og Bibliotek. Tema LO 100 år. Oslo: LO media, pp. 56-83. 
Kjellberg, A. (2000) 'Arbetsgivarstrategier i Sverige under 100 år.' [Employer strategies in Sweden in the course of 100 years.] In: Jensen, CS. (ed) Arbejdsgivere $i$ Norden. En sociologisk analyse af arbejdsgiverorganisering $i$ Norge, Sverige, Finland og Danmark. København: Nordisk Ministerråd, pp. 155-284.

Kjellberg, A. (2009) 'Industrial relations foresight for Sweden: Presentation of results and comments.' Lund University: Studies in Social Policy, Industrial Relations, Working Life and Mobility. Research Reports 2009: 1.

Kocka, J. (2003) 'Comparison and Beyond.' History and Theory 42: 29-44.

Korpi, W. (1978) The Working Class in Welfare Capitalism. Work, Unions and Politics in Sweden. London: Routledge \& Kegan Paul.

LO (1980) 'Videreutvikling av bedriftsdemokrati. Utredning og innstilling fra en felles komité mellom Landsorganisasjonen i Norge og Det Norsk Arbeiderparti.' [The further development of industrial democracy: Report from a joing committee of the national trade union organization and the Norwegian Labor Party]. Oslo.

LO (2014) Hovedavtalen mellom LO/NHO, 2013-2017, [Main Agreement between LO/ NHO], Chapter XIII: http://www.lo.no/Documents/Lonn_og_tariff/hovedavtalene/Hovedavtalen\%20LO-NHO.pdf (accessed 6 May 2014).

Lundh, C. (1987) Den svenska debatten om industriell demokrati 1919-1924. I. Debatten $i$ Sverige. [The Swedish debate on industrial democracy 1919-1924. I. The debate in Sweden.] Lund: Studentlitteratur.

Løken, E. and Stokke, TA. (2009) 'Labour Relations in Norway.' Oslo: Fafo-report 2009: 33.

Madsen, A. (1919) Industrielt selvstyre. Et indloeg $i$ spørsmaalet om arbeiderkontrol. [Industrial self-government. A contribution on the question of workers' control.] Kristiania: Det norske Arbeiderpartis forlag.

Madsen, A. (1920) Raadssystemet og socialiseringen. [The council system and socialization.] Kristiania: Arbeiderpartiets og Landsorganisationens socialiseringskomite.

Marx, K. (1972) [1890] Das Kapital. Kritik der politischen Ökonomie. Dritter Band. Der Gesamtprozeß der kapitalistischen Produktion. [Capital. Volume III. The Process of Capitalist Production as a Whole.] Berlin: Dietz Verlag.

Meine, H., Schumann, M., Urban, H-J. (eds) (2011) Mehr Wirtschaftsdemokratie wagen! [Dare more economic democracy!] Hamburg: VSA Verlag.

Myrvang, C. (2001) 'West of Eden - Norwegian Industry in the Shadow of Swedish Grandeur 1914 to 1940.' In: Byrkjeflot, H., Myklebus, S., Myrvang, C. and Sejersted, F. (eds) The Democratic Challenge to Capitalism: Management and Democracy in the Nordic Countries. Oslo: Fagbokforlaget, pp. 151-178.

Nergaard, K. (2010) 'Fagorganisering i Norden. Status og utviklingstrekk.' [Union organization in the Nordic countries. Status and developmental trends.] Fafo-notat 2010: 25.

NOU (2010) Medvirkning og medbestemmelse i arbeidslivet 2010:1. [Participation and codetermination in working life.] Available at: http://www.regjeringen.no/pages/2469736/ PDFS/NOU201020100001000DDDPDFS.pdf (accessed 5 January 2014).

Olstad, F. (2010) Frihetens århundre. Norsk historie gjennom de siste hundre arr. [The century of liberty. Norwegian history through the last hundred years.] Oslo: Pax Forlag.

Polanyi, K. (2001) [1944] The Great Transformation. The Political and Economic Origins of Our Time. Boston: Beacon Press.

Ragin, CC. (1987) The Comparative Method: Moving Beyond Qualitative and Quantitative Strategies. Berkeley: University of California Press.

SAP (1920) Protokoll från Sverges Socialdemokratiska Arbetarpartis congress 8-15 februari 1920. [Protocol of the Swedish Social Democratic Party's congress 8-15 February 1920.]

Schiller, B. (1967) Storstrejken 1909. Förhistoria och orsaker. [The big strike 1909. Prehistory and causes.] Göteborg: Elanders Boktryckeri. 
Schiller, B. (1974) LO, paragraf 32 och företagsdemokratin. [LO, paragraph 32 and industrial democracy.] Stockholm: Prisma.

Schiller, B. (1990) Samarbete eller konflikt. Medbestämmandet i Sverige 1965-1982. [Cooperation or conflict. Co-determination in Sweden 1965-1982.] In: Fleming, D. (ed) Industriell demokrati i Norden. Lund: Arkiv förlag, pp. 293-326.

Skocpol, T. and Somers, M. (1980) 'The Uses of Comparative History in Macrosocial Inquiry.' Comparative Studies in Society and History 22(2): 174-197.

Sejersted, F. (1993) Den norske "Sonderweg”. [The Norwegian 'Sonderweg'.] In: Sejersted, F. Demokratisk kapitalisme. Oslo: Universitetsforlaget, pp. 163-206.

Sejersted, F. (2011) The Age of Social Democracy. Norway and Sweden in the Twentieth Century. Princeton: Princeton University Press.

Slagstad, R. (2001) De nasjonale strateger. [The national strategists.] Oslo: Pax forlag.

Socialdemokraterna \& Arbetarrörelsens arkiv och bibliotek (ed) (2001) Socialdemokratins Program 1897 till 1990, [The program of social democracy 1897 to 1990], Stockholm. Available at: http://www.arbark.se/pdf_wrd/partiprogram_pdf.pdf (accessed 5 January 2014).

Stenlås, N. (2001) 'The Rise of Political Activism in Scandinavian Big Business 1900-1950.' In: Byrkjeflot, H., Myklebus, S., Myrvang, C. and Sejersted, F. (eds) The Democratic Challenge to Capitalism: Management and Democracy in the Nordic Countries. Oslo: Fagbokforlaget, pp. 265-290.

Stortingstidende (1971-1972) 'Lov nr. 26 om endringer i lov av 6. juli 1957 om aksjeselskaper, datert 12. mai 1972' [Law nr. 26 on changes in the law of July 61957 on limited liability companies, dated May 12 1972]. Available at: https:/www.stortinget.no/no/ Saker-og-publikasjoner/ Stortingsforhandlinger/Lesevisning/?p=1971-72\&paid=8\&wid= a\&psid=DIVL286\&pgid=a_0887 (accessed 6 May 2014).

Streeck, W. (1979) 'Gewerkschaftsorganisation und industrielle Beziehungen. Stabilitätsprobleme industriegewerkschaftlicher Interessenvertretung.' [Trade union organization and industrial relations. Problems of stability of representation of interests by industrial unions.] Gewerkschaftliche Monatshefte 30(11): 721-733.

Streeck, W. and Hassel, A. (2003) 'Trade Unions as Political Actors.' In: Addison, JT. and Schnabel, K. (eds) International Handbook of Trade Unions. Cheltenham: Edward Elgar Publishing, pp. 335-365.

Stråth, B. (2001) 'Nordic Capitalism and Democratisation.' In: Byrkjeflot, H., Myklebus, S., Myrvang, C. and Sejersted, F. (eds) The Democratic Challenge to Capitalism: Management and Democracy in the Nordic Countries. Oslo: Fagbokforlaget, pp. 51-86.

Svensk Författningssamling (2014a) Lag (1987:1245) om styrelserepresentation för de privatanställda. [Swedish Board Representation (Private Sector Employees) Act.] Available at: http://www.notisum.se/rnp/sls/lag/19871245.HTM (accessed 6 May 2014).

Svensk Författningssamling (2014b) Lag (1976:580) om medbestämmande i arbetslivet. [Swedish Co-Determination in the Workplace Act.] Available at: http://www.notisum.se/ Pub/Doc.aspx? url=/rnp/sls/lag/19760580.htm (accessed 6 May 2014).

Svensk Författningssamling (2014c) Lag (1976: 351) om styrelserepresentation för de anställda i aktiebolag och ekonomiska föreningar [Law on employee board-level representation in limited companies and economic associations]. Available at: http://www.notisum.se/ Pub/Doc.aspx? url=/rnp/sls/lag/19760351.htm (accessed 6 May 2014).

Welskopp, T. (2010) 'Comparative History.' European History Online (EGO), published by the Institute of European History (IEG), Mainz. Available at: http://www.ieg-ego.eu/welskoppt-2010-en (accessed 14 October 2013).

Von Beyme, K. (1977) Gewerkschaften und Arbeitsbeziehungen in kapitalistischen Ländern. [Trade unions and industrial relations in capitalist countries.] München: Piper. 


\section{End notes}

1 Demirović (2007, p. 30) uses the German term "Mitbestimmung”, which could also be translated as co-determination. He puts most emphasis on participation through unions, but a "democratic attitude among wage earners" can also contribute to direct participation in the work process, without necessarily involving unions. "Education, skills and hierarchical position" are also relevant for direct participation (Hagen \& Trygstad, 2009, p. 563). The article focuses on the challenges related to representative participation. It should also be noted that the term "participation" is used in the EU/EEA context only with relation to participation on the board, not in works councils. In this article, both institutions are considered forms of participation.

2 Reasons for this might be insufficient knowledge as well as different class habitus, putting worker representatives in a position of inferiority. This also contains a danger of overcompensation, for example, when worker representatives try to speak, act and dress just like business men, to the extent that they can no longer be distinguished from the opposite party (Demirović, 2007, p. 43).

3 This assertion is not meant to question that current models of worker participation lead to a certain level of democratization. Analyses of Gold (2011), Demirović (2007) and, for Norway, Falkum et al. (2009), Hagen (2010) and Heiret (2000), clearly show that worker representatives have some relevant influence within their companies. But the underlying contradiction between the workers' interest in democratization and class cooperation and the management's interest in competition and increased profit remains (cf. Heiret, 2000, p. 304).

4 Both the Norwegian and the Swedish Federation of Trade Unions are called LO ("Landso rganisasjonen"/“Landsorganisationen").

5 In Sweden, universal male suffrage was granted in 1909, and women received the right to vote in 1918. In Norway, the same happened in 1898 and 1913 respectively. Sejersted (2011, p. 11) points this out as a major difference between the two countries: "At the risk of oversimplifying, one could say that Norway was democratized before it was industrialized, while the opposite was the case in Sweden. This difference has distinguished the two countries' development trajectories up to the present day, not least in the conspicuous strength of democratic norms in Norway."

6 There are of course several reasons for this, for example, the fact that unemployment insurance is administered by the unions in Sweden, but not in Norway, and the fact that separate white-collar unions have been more successful in Sweden than in Norway (cf. Kjellberg, 1999, 2009; Nergaard, 2010).

7 Heiret (2003a, p. 138) and Bergh (1983, p. 95) assume that the labor party included board-level representation in its 1954-program to prove that they were still a party for the working class, despite having moderated its politics in other areas. Bergh (1983, p. 89) also points out that board-level representation was included in the first after-war program ("Fremtidens Norge") and supported by some union leaders, but was dropped in the summer of 1945 due to growing skepticism.

8 Already in 1942, Swedish employers had founded the propaganda organization Libertas, which gave out 17.8 million kronors to conservative newspapers between 1942 and 1950 . The Norwegian Libertas was not founded until 1947 and created so much public opposition that it could not achieve very much (Stenlås, 2001).

9 Today: The Confederation of Norwegian Enterprise (NHO).

${ }^{10}$ The Main Agreement states that private companies with more than 100 employees must have company councils. Statistically representative figures by Falkum et al. (2009) show that about one-third of Norwegian companies with more than 50 employees has company councils, with another third of employees and managers reporting that they do not know whether company councils are established. 
11 This must be why Hagen and Trygstad (2009, p. 563) claim that "at company level, the management's counterparts are the local branch of the national trade union. Works councils elected by all the employees [...] do not exist in Norway." They seem to take the domination of company councils and work environment committees by union members as a given, even though this is clearly not based on any legal documents.

12 Large companies with over 200 employees are required to have company assemblies, of which employees can vote a third. In companies with over 50 employees, employees can demand to vote up to a third of the board of directors, and at least one representative and one substitute, if the company has more than 30 employees. If it is decided by agreement that a company with more than 200 employees shall not have a company assembly, employees can vote one additional member of the board (Justis-og beredskapsdepartementet, 1997a,b).

${ }^{13}$ Workers have $50 \%$ representation in work environment committees ("arbeidsmiljøutvalg”) and their representatives are voted among all employees (Justis- og beredskapsdepartementet, 2011). Work environment committees can obligate the employer to implement work protection measures. In addition, health and safety representatives ("verneombud") chosen by local unions can stop production in cases of danger (Heiret, 2003a, pp. 167ff). In a statistically representative survey, two thirds of employees in Norwegian companies with more than 50 employees report that work environment committees are established (Falkum et al., 2009). For a detailed analysis of the political debate leading to the Working Environment Act, see Falkum (2008).

${ }^{14}$ The idea of wage earner funds was introduced by the Swedish LO in 1971. The funds were meant to slowly transfer a portion of private profits into collective ownership. They were introduced in a watered-down version in 1983 and abolished again in 1991 (for a more comprehensive discussion, see for example Sejersted, 2011, pp. $372 \mathrm{ff}$ and Esping-Adersen, 1985, pp. 289ff).

${ }^{15}$ Quantitative, comparative data on ownership concentration are very hard to come by, as Esping-Andersen (1985, p. 54) already pointed out. This lack of data has unfortunately not been amended since then (but c.f. Grünfeld et al., 2006). However, there seems to be a consensus in the literature that there was, and presumably still is, more and more highly concentrated private capital in Sweden and that Swedish big business was also better organized (cf. Esping-Andersen, 1985; Myrvang, 2001; Sejersted, 2011; Stenlås, 2001; Stråth, 2001). This would merit further research. 